Dr SRĐAN CVETKOVIĆ, naučni saradnik

Institut za savremenu istoriju

UDK 323.282(497.1)"196/198"

Beograd, Trg Nikole Pašića 11

616.89-035.3:32"196/198"

\title{
KO JE OVDE LUD? \\ Primeri političke (zlo)upotrebe psihijatrije u SFRJ ${ }^{*}$
}

\begin{abstract}
APSTRAKT: Članak se bavi pitanjem zloupotrebe psihijatrije u političke svrhe u SFRJ i drugim komunističkim zemljama. U autoritarnim režimima, posebno masovno u SSSR-a a delimično u ostalim socijalističkim zemljama i Jugoslaviji, postojala je zloupotreba psihijatrije gde su se lica koja su istupala protiv režima veštačila kao opasna po okolinu i kao takva osuđivana na meru bezbednosti tj. neograničen boravak u zatvorskim neuropsihijatrijskim bolnicama. Time se na posredan način sakrivao broj političkih osuđenika i disidenata.
\end{abstract}

Ključne reči: zloupotreba psihijatrije, disidenti, SFRJ, politička represija, komunizam

U državama liberalne demokratije ne postoji „delikt mišljenja“ jer reč i misao ne mogu biti predmet krivično-pravnog progona, bez obzira da li su u pitanju duševno zdrava ili bolesna lica. Pogrešno, kritičko, neučtivo i izopačeno mišljenje nije stvar suda, osim kada se radi o zaštiti moralnog integriteta pojedinaca ili grupa koji su oklevetani ili uvređeni, pa svojom inicijativom pokreću postupak. U totalitarnim državama a u SFRJ od početka sedamdesetih godina 20 . veka pa i ranije mogu se uočiti primeri zloupotrebe psihijatrije gde se disidenti i lica nekonformističkog ponašanja „zbog kritičkih izjava i postupaka na račun vlasti i ideologije, ili svoje nepodobnosti, umesto osude za delikt mišljenja šalju na neodređeno vreme na lečenje u ustanovu psihijatrijskog tipa kao „opasna po okolinu“. Na taj način se formalno smanjuje broj političkih osuđenika u zemlji.

Zloupotrebu psihijatrije $u$ političke svrhe prvi je $u$ sistem uveo Musolini, a model "totalne psihijatrije" naročito se raširio u Trećem rajhu i u

* Rad je deo projekta Konflikti i krize: saradnja i razvoj u Srbiji i regionu u 19. i 20. veku (47030), koji finansira Ministarstvo prosvete, nauke i tehnološkog razvoja Republike Srbije. 
Španiji, ali je primećen i u Kraljevini Jugoslaviji i drugde, kasnije u svim staljinističkim zemljama. Metod je najpre, do neslućenih razmera, razvio Hitlerov režim usvajanjem zakona o ubijanju duševnih bolesnika, radi „očuvanja rase". Zloupotreba psihijatrije u političke svrhe javlja se zatim masovnije u SSSR-u i drugim komunističkim zemljama od kraja 50-ih, naročito u uslovima relativne liberalizacije i destaljinizacije i pod uticajem potrebe da se prikrije stvaran broj političkih osuđenika. ${ }^{1} \mathrm{Za}$ utamničenje nepodobnih disidenata u ludnice, najčešće psiho-političke „dijagnoze“ zbog kojih ih je trebalo prisilno „lečiti“ u režimskim psihozatvorima bile su: kritikomanija ili „suludo kritizerstvo“ (Paranoia querulans) i „puzeća-podmukla shizofrenija" (Schizophrenia torpida) koju je osmislila već Staljinova sovjetska psihijatrija. Psihijatrijski konclogori (na kineskom ankang, na ruskom psyhuška) bili su specijalni logori gde se medicinska psihijatrija zloupotrebljavala za prisilno 'ispravljanje' tj. duševne izmene političkih disidenata (većinom akademskih intelektualaca) otrovnim psihofarmakima. Navode se podaci da je pod Staljinom u Sovjetskom Savezu, „ispiranje mozga“ kroz staljinske „psihuške“ navodno prošlo čak 335.200 ideoloških robijaša (što je verovatno preterano ali je svakako postojala masovna praksa). Prvi put je o tome pisala sovjetska štampa (list Izvestija) tek tokom perestrojke 1987. godine. Ipak i u periodu 1987-1989, prema ocenama Amnesti internešenela, bilo je oko 2000 sumnjivih slučajeva zloupotrebe psihijatrije. u šta su se uverile međunarodne komisije koje su bile na ispitivanjima posle 1989. godine. Posle raspada SSSR-a i propasti komunizma, u Rusiji su od 1989. takvi psihologori delom zatvoreni ili vraćeni u pravu medicinsku upotrebu psihijatrijskih bolnica. Ova sovjetska praksa je potom najviše kopirana u Kini, Kubi, Rumuniji, Istočnoj Nemačkoj i delimično u Jugoslaviji gde međunarodne organizacije beleže i po više desetina slučajeva godišnje tokom 70-ih godina prošlog veka.2 U SFRJ je naročito ustavnim reformama iz 1974. (zlo)upotreba psihijatrije uvedena na velika vrata u pravosudni sistem. U komentaru Krivičnog zakonika SFRJ, uz član za primenu mere bezbednosti (koja se u praksi izvrgla u robiju na neodređeno vreme), ekspli-

${ }^{1}$ Možda najpoznatiji slučaj zloupotrebe psihijatrije u SSSR-u jeste onaj generala Petra Grigorjenka, koji je u poststaljinističko vreme na konferenciji partijskog aktiva svoje armijske oblasti kritikovao režim sa „autentično marksističko-lenjinističke platforme“. Zatvoren je u psihijatrijsku kliniku, odakle ga je posle više godina borbe uspela spasiti demokratska svetska javnost. Pre njega se govorilo o zloupotrebi psihijatrije i u slučaju matematičara Aleksandra Volopina, British Medical Association, Medicine Betrayed, The participation of doctor in Human rights abuses, internet izdanje knjige na http://books. google. ru/books? $\mathrm{id}=\mathrm{bMTu}$ oIfVsIC\&printsec $=$ frontcover\# $\mathrm{v}=$ onepage\&q\&f=false

$\overline{2}^{\overline{2}}$ British Medical Association, Medicine Betrayed, The participation of doctor in Human rights abuses, internet izdanje knjige http://books. google. ru/books? $\mathrm{id}=\mathrm{bMTu}$ _oIfVsIC\&printsec $=$ frontcover $\# \mathrm{v}=$ onepage\& $\mathrm{q} \& \mathrm{f}=$ false 
citno je pomenuto da je korišćeno iskustvo italijanske psihijatrije između dva rata (što je svojevrstan paradoks budući da se 70 -ih Italija odricala iskustva koje se u praksi pokazalo problematično). ${ }^{3}$

\section{Kako se dospevalo u ludnicu?}

Metodologija zloupotrebe bila je sledeća: osoba koja kritikuje vlast ili na drugi način dođe u raskorak sa režimom i ideologijom najpre se psihijatrijskim veštačenjem oglasi neuračunljivom i opasnom po okolinu i time se izbegne politički proces pred sudovima (mogući negativan publicitet $\mathrm{u}$ javnosti itd.). Zatim se odredi lečenje na neodređeno vreme u neuropsihijatrijskoj ustanovi zatvorenog tipa. Inicijativu za obustavljanje mere bezbednosti mogli su jedino da pokrenu sami psihijatri koji su kao veštaci Sekretarijata unutrašnjih poslova bili vrlo rezervisani prema „neprijateljima drža$v e^{\prime \prime}$, jer je trebalo da garantuju da lice neće ponoviti delo na slobodi. Kada se i pokrene inicijativa za oslobađanje, nailazi se na još veću prepreku. Izlazi se pred Komisiju koju čine i političari, a koja bez konsenzusa ne može da donese odluku o otpustu. Vremenom se boravkom u ovakvim ustanovama inače labilno psihičko stanje pritvorenih uglavnom naglo pogoršava, pa $\mathrm{u}$ takvim uslovima čak i oni relativno normalni počinju da duševno obolevaju. Čest je takođe bio slučaj da se lica pošalju u neuropsihijatrijske bolnice bez ikakve dokumentacije i presude i tamo drže neodređeno vreme.

U socijalističkoj Jugoslaviji ovaj fenomen je naročito učestao od polovine 70 -ih, jačanjem civilnog sektora, potpisivanjem međunarodnih deklaracija o ljudskim pravima i težnjom režima da se Jugoslavija posle reformi tokom 50-ih godina predstavi kao zemlja liberalnog socijalizma. Kritika vlasti i izražavanje slobodnih i kritičkih stavova i mišljenja bili su razlog da se osoba umesto zatvorskom kaznom za politički prekršaj, proglasi za čoveka opasnog po okolinu i to bez dokumentacije i dokaza. Time se na neki način „sakrivao“ stvaran broj političkih osuđenika, a ovakva zloupotreba bila je sredstvo socijalne i političke kontrole u rukama represivnog aparata. Eksploatisan je pojam „opasan po okolinu“, a pod širokim i rastegljivim tumačenjem podrazumevalo se i ono što bi se moglo podvesti pod ideološko-političku diverziju (najčešće: neprijateljska propaganda, širenje lažnih vesti, izazivanje rasne, nacionalne i verske mržnje i netrpeljivosti, uvreda državnih organa, povreda lika i dela J. B. Tita i slični politički delikti). ${ }^{4}$

${ }^{3}$ T. Krsmanović, Ko je ovde lud, Beograd 2004.

${ }^{4}$ Odbor za odbranu slobode misli i izražavanja, Dokumenti i saopštenja 1984-1986, Beograd 1986, dok. br. 12, 37-38. 
Apeli i peticije međunarodnih i domaćih nevladinih organizacija ukazuju na to da su se psihijatri češće i mnogo lakše odlučivali da pod trajan nadzor u ustanovi zatvorenog tipa stave političke krivce od lakših nepolitičkih. ${ }^{5}$ Psihijatrijska struka je pod kategorijom „neuračunljiv“ podrazumevala osobu koja u momentu izvršenja krivičnog dela nije mogla da shvati značaj svog dela, niti upravlja postupcima usled trajne ili privremene duševne bolesti. Stručno veštačenje preduzimano je isključivo $u$ istražnom postupku i njega je određivao organ koji vrši postupak. Mišljenja pravnika i psihijatara bila su podeljena - dok su prvi zastupali tezu da su veštaci dužni da pred sudom nemaju lekarskih tajni već da sve saopšte sudskim organima, psihijatri su se držali stanovišta da se mora posvetiti puna pažnja lekarskoj etici i zaštiti ličnosti. ${ }^{6}$

Kao pravni osnov za izricanje mere lečenja pod nadzorom u neuropsihijatrijskoj ustanovi zatvorenog tipa korišćen je najpre čl. 61 Krivičnog zakonika iz 1951. i kasnije čl. $63 \mathrm{KZ}$ iz 1977. koji propisuje meru bezbednosti počiniocu krivičnog prestupa za koga se ustanovi psihička neuračunljivost i opasnost po okolinu. Mere bezbednosti su prema krivično neodgovornim licima u periodu 1966-1968. određene u 52 slučaja, mahom prema izvršiocima krvnih delikata, dok se ne zna za slučajeve političke zloupotrebe koji se javljaju od početka 70-ih (što ne mora da znači da ih nije bilo!). Osuđeni su izdržavali kaznu u zatvorskim bolnicama, ali nije bila retkost da su smeštani u sudska odeljenja civilnih bolnica, a funkcionisanje ovih bolnica regulisano je Zakonom o izvršavanju krivičnih sankcija. ${ }^{7}$ Ova mera se mogla izreći samo ako je okrivljenik opasan po okolinu, tj. u slučaju ako je zbog duševne bolesti sklon napadu na život i telo drugih lica bez razloga i povoda, pa se u smislu čl. $12 \mathrm{KZ}$ SFRJ smatra neuračunljivim. ${ }^{8}$ Dva su osnovna načina zloupotrebe kada su u pitanju verbalni i politički delikti: $s$ jedne strane montiranjem dokaza, nameštanjem provokacijama tajne policije, za lice koje je predmet obrade, i s druge, veštačenjem preko „svojih ljudi“ u sudovima i neuropsihijatrijskoj struci. Na taj način su mnogi (M. Živanović, R. Veljković, V. Marković i drugi) iako zaista nenasilni, osuđeni zbog verbalnog delikta na neograničen boravak u psihijatrijskoj ustanovi zatvorenog tipa, gde su neki proveli i po više od deceniju. Tako su za svoje "ogrešenje“ dobili strožu kaznu budući da su za ovakve prestupe obično izricane kazne

${ }^{5}$ K. Čavoški, Preliminarni izveštaj o zloupotrebi psihijatrije u političke svrhe, 15. februar 1985, Odbor za zaštitu sloboda misli i izražavanja - u posedu autora.

${ }^{6}$ Prvo savetovanje republičkog udruženja za krivično pravo i kiminologiju, Penološki glasnik, 1980, 30-48.

${ }^{7}$ AJ, Vrhovni sud Jugoslavije, 212, fasc. 111, 9/16, Primena mera bezbednosti, Mere bezbednosti prema krivično neodgovornim licima, 14.

${ }^{8}$ R. Danilović, Upotreba neprijatelja, Valjevo 1993, 103-104. 
do 2-3 godina zatvora. Radnica Centralnog zatvora u Beogradu Gordana Milojević, koja je ceo radni vek provela u IV-B odeljenju ovog zatvora, potvrđuje da su mnogi koji su prošli kroz to odeljenje bili zapravo bezopasne i nesrećne ličnosti. Mnogi su bez ikakve presude držani u tim ustanovama: „Mnogo je bilo tih bez presude. Doktori su često imali problema da neko lice otpuste tj. izreknu prekid mere jer zapravo nema validnog osnova zašto je lice inače u zatvorskoj bolnici... Tako su pojedina lica godinama bila kako da kažem na "stend baju" čekajući slobodu jer se nije znalo šta sa njima." ${ }^{9}$ Što se zatvorskih uslova tiče ishrana je bila solidna, posete dozvoljene jednom nedeljno po 45 minuta, ali generalno su uslovi bili loši i zimi jako hladno: „Celi radni vek provela u čizmama i kaputu jer su prozori bili dotrajali a grejanje i izolacija slabi." "Politički“" su se uglavnom držali vrlo korektno prema osoblju: „Bilo je slučajeva kada se naši štićenici otpuste da nas zovu i prepoznaju na ulici jer se vežu i misle da su kod nas našli razumevanja koje im inače fali kada se vrate u "normalnu sredinu“ gde po pravilu nailaze na nerazumevanje i prezir." 10

Prvi put se o zloupotrebama psihijatrije i položaju ovih pacijenata progovorilo početkom osamdesetih. Aprila 1981. osnovano je u Beogradu Društvo za borbu protiv zloupotreba psihijatrije u političke svrhe i zaštitu ljudskih prava - Akcija (1990. preimenovano u Pokret za zaštitu ljudskih prava u Jugoslaviji) na čijem čelu se nalazio ekonomista Tomislav Krsmanović, a među osnivačima su bili književnik Dragoljub Ignjatović, novinar Vladimir Marković, pravnik Golub Bakić, prof. Boda Marković, prof. Božidar Todorović. Društvu je pristupilo na desetine članova iz cele Srbije. Među osnivačima i članstvom bile su mahom žrtve progona ili torture režima, a dobar deo njih je i sam bio žrtva (zlo)upotrebe psihijatrije. Slična neformalna organizacija postojala je pod imenom Korjagin, čiji su članovi bili dr Veselin Ilić i dr Rugelj, Janez Janša, Dobrosav Paraga, Ivan Stojanović i drugi. Radila je na obaveštavanju strane i domaće javnosti o zloupotrebama psihijatrije $u$ političke svrhe u SFRJ. ${ }^{11}$ Mnoge zloupotrebe psihijatrije tokom 70-ih ih i 80-ih u Srbiji detaljnije su dokumentovali u knjigama Vladimir Marković i Tomislav Krsmanović (1988) i sami žrtve zloupotreba, a odnedavno se u Hrvatskoj time bave T. Dragun i T. Pensa. ${ }^{12}$

${ }^{9}$ Svedočenje Gordane Milojević, penzionisanog radnika Centralnog zatvora Beogradu - B odeljenja zatvorene neuropsihijatrijske bolnice.

${ }^{10}$ Isto.

${ }^{11}$ Ime Korjagin je uzeto po A. Korjaginu, ruskom neuropsihijatru, koji se prvi usprotivio zloupotrebi psihijatrije u političke svrhe. - Svedočenje Ivana Stojanovića iz Beograda dato autoru 15. januara 2009.

${ }^{12}$ T. Krsmanović, Ko je ovde lud, Beograd 2004; V. Marković, Disidentske uspomene, Beograd 1998. 


\section{Slučajevi}

Potresne su sudbine lica koja su, bez obzira da li je reč o zdravim, bolesnim ili graničnim slučajevima, smeštana u duševne bolnice samo zbog verbalnih iskaza. Postoji na desetine poznatijih slučajeva političkih delinkvenata koji su bili žrtve zloupotrebe psihijatrije, priznatih od međunarodnih organizacija za zaštitu ljudskih prava. Svakako je najpoznatiji i najteži slučaj Radomira Veljkovića (Gari, Kruševac 1926-2006), penzionisanog pukovnika JNA i borca Rasinskog partizanskog odreda. Posle rata ostao je u vojsci završivši četiri vojne škole i postdiplomske studije na Višoj vojnoj akademiji. Od 1964. bio je nastavnik na Vojnoj akademiji, predmet artiljerija (za uspeh na Vojnoj akademiji dobio je počasnu diplomu Titovog pitomca). Prevremeno je penzionisan 1967, u četrdesetoj godini, pod izgovorom smanjenja potrebe za kadrovima, upravo posle Brionskog plenuma. Naivno shvatajući liberalizaciju posle ovog plenuma, Veljković podnosi tužbu sudu okrivljujući Tita za represiju, greške i odgovornost za stradanja mnogih boraca u Drugom svetskom ratu. Nacionalna tragedija na Sutjesci ne zbog ranjenika nego zbog engleskog oficira - ovako je naslovio dvadesetak gusto kucanih stranica teksta svoje istoriografske studije o petoj neprijateljskoj ofanzivi koju je u formi optužnog predloga predao Okružnom sudu u Beogradu s namerom da se utvrdi istina o bici na Sutjesci. U spisu je osporio Titovu taktiku govoreći da je on znao za ofanzivu, ali da nije preduzeo potrebne korake, te se, navodno, partizanska vojska zbog čekanja engleskog oficira našla u okruženju (po njemu, taktika je bila pogrešna zbog deset dana čekanja, od 18. do 28. maja 1943, kada je neprijateljska vojska stvorila uslove za okruženje). U proširenoj optužnici od 14. maja 1969. Veljković direktno optužuje Josipa Broza Tita za progon ljudi i masovna kršenja ljudskih prava, „a naročito su na udaru progona bili članovi partije i nosioci naše revolucije". Ustvrdio je da je i u Jugoslaviji staljinizam uhvatio korena „s tom razlikom što su Sovjeti na 22. kongresu rehabilitovali nevino osuđene žrtve, a mi to nismo učinili“. Takođe da je bilo na hiljade slučajeva uklanjanja, penzionisanja i suđenja ratnih oficira (da je za 20 godina otpušteno preko 20.000 starih i primljeno isto toliko novih oficira). Govori o torturi i mučenju $u$ istražnom postupku, gde su se priznanja izvlačila silom navodeći kao primer Prizrenski proces (osuđeno 9 Albanaca na kazne 2-12 godina zbog špijunaže u korist Albanije). U svojoj tužbi Veljković niže primere instrumentalizacije sudova, pritiske na porodicu, različite oblike progona protivnika režima. ${ }^{13}$

${ }^{13}$ Optužnica Radomira Veljkovića protiv Josipa Broza Tita pred Okružnim sudom u Beogradu, K. br. 74/69, 14. maj 1969, kopija u posedu autora. 
Umesto utvrđivanja činjenica i naučne rasprave, Veljković je zbog verbalnih kritika vlasti i nenasilnog izražavanja mišljenja proglašen duševnim bolesnikom opasnim po okolinu i poslat u ludnicu. Rešenjem OKS u Sarajevu 20. marta 1973. izrečena mu je mera obaveznog lečenja u ustanovi zatvorenog tipa, zbog teksta u formi optužnog predloga protiv predsednika SFRJ J. B. Tita. Prema podacima Odbora za odbranu slobode misli i izražavanja u Psihijatrijskoj bolnici CZ-a u Beogradu proveo je 15 godina. U momentu zatvaranja, Radomir Veljković je posedovao uredne nalaze nadležnih institucija da je psihički zdrav i sposoban za rad. ${ }^{14} \mathrm{U}$ presudi Suda $\mathrm{u}$ Sarajevu iz 1973. godine piše: „Okrivljeni tvrdi da se zakoni masovno krše, da su zavladali nepotizam i korupcija, da se ljudska prava masovno krše, što vodi ubrzanoj i rastućoj opasnoj društvenoj krizi i raspadu države, te da slabi njenu vojnu i odbrambenu moć. Iznoseći ovakve neistine, Veljković je počinio krivična dela klevete države i njenih organa i neprijateljske propagande". Na suđenju mu je, protivno zakonu, oduzeta poslovna sposobnost. U jednom intervjuu o metodologiji progona on kaže: „Po zakonu niko ne može biti kriv ni lud pre pravosnažne odluke u zakonitom postupku. Međutim, u praksi se uz fingiranje psihijatrije uvek izigrava zakon. To se naročito čini kad su u pitanju politički slučajevi, kako su i moj slučaj krstili. Mene su odmah po zatvaranju proglasili ludim, a da me niko nije saslušao ni pregledao, nisu me izvodili ni na sud. Kasnije sam saznao da je, navodno, bio neki psihijatar i da je napisao mišljenje proglasivši me bolesnim. Nisu mi dali nikakvu mogućnost da se branim. Advokat koga sam angažovao, Pera Znoar iz Mostara, uhapšen je uoči mog suđenja, a određen je jedan njihov čovek po službenoj dužnosti. Nikad ga nisam ni video, niti je on mene branio kao stranku. Imaju oni u Okružnom sudu formiran predmet, ali niko meni nikad ništa nije dao. Postoji i optužnica i veštačenje psihijatara i presuda... a zašto sve zbog te studije o Petoj ofanzivi." Na obavezno lečenje u Beograd upućen je odlukom Višeg suda u Sarajevu 20. marta 1972, a $\mathrm{u}$ beogradsku bolnicu je primljen u julu. Od tada počinje njegova borba za slobodu i napori da dokaže birokratiji da je zdrav. Veljković govori da je čak od uprave, budući vrlo obrazovan, bio angažovan za pisanje istorije bolesti za sudska veštačenja optuženih: „Radio sam sve, osim fizičkih poslova. Vrhunac u mom protivzakonitom angažovanju jeste poverenje koje su mi ukazali lekari. Angažovali su me da za njihove potrebe pišem, pazite sad, istoriju bolesti za sudska veštačenja optuženih. Te istorije bolesti su tajna i sa stanovišta medicine i sa stanovišta sudstva. Ali nema veze, oni meni daju, oni

${ }^{14}$ Neuropsihijatrijski nalaz Kliničke bolnice u Sarajevu, 19. decembar 1967; Neuropsihijatrijski nalaz Doma zdravlja „Omir Maslić“ u Sarajevu, 8. februar 1968; Neuropsihijatrijski nalaz Medicinskog centra u Zenici, 4. avgust 1970; Neuropsihijatrijski nalaz neuropsihijatrijske klinike Medicinskog fakulteta u Beogradu, 24. januar 1968. - Arhiva Pokreta za ljudska prava Srbije; Odbor za odbranu slobode misli i izražavanja, Dokumenti i saopštenja 1984-1986, Beograd 1986, dok. br. 12, 37-38, 39-44. 
samo potpišu i uzmu debeli honorar. Kroz moje ruke je prošlo 15.000 istorija bolesti, ja ludak, kako me proglasiše psihijatri, a pišem istorije bolesti i ekspertize. " ${ }^{15}$ Ovo potvrđuje u svojim sećanjima i Gordana Milojević, bivša radnica neuropsihijatrijskog odeljenja na kojem je bio Veljković: „Radomiru Veljkoviću su čak doktori poveravali odredene poslove, bio je jako ljubazan i odgovoran, često je on vodio računa o drugima i o disciplini. Niko nije znao zašto je on tu...". ${ }^{16}$

Veljković je, bez presude i rešenja, u pritvoru proveo 15 godina. Za njegovo oslobađanje založili su se Amnesty internešenel i više od 30 beogradskih intelektualaca. Ulagao je žalbu Organizaciji ujedinjenih nacija, a njegov brat Dragan Veljković (na različite načine proganjan posle 1945) pisao je više puta i tražio oslobođenje brata, između ostalih i Petru Stamboliću, predsedniku Predsedništva SFRJ (marta 1983). U apelima i izveštajima Odbora za zaštitu slobode misli i izražavanja, se, pored slučaja Veljković, ukazuje na zloupotrebu psihijatrije u slučaju novinara V. Markovića (oslobođen maja 1982) i traži oslobađanje M. Živanovića, D. Ćetkovića, V. Naglića i B. Boričića. ${ }^{17}$

Posle mnogih apela i pritiska domaće intelektualne javnosti (Udruženja književnika, Odbora za odbranu slobode misli i izražavanja, Pokreta za zaštitu ljudskih prava), međunarodnih organizacija, apela svetskih medija (Glas Amerike, BBC...) i porodice - Okružni sud u Sarajevu je konačno doneo rešenje u kojem se konstatuje da je komisija tokom 1986. utvrdila da je duševno zdravlje Veljkovića poboljšano, pa je 17. marta 1986. otpušten iz bolnice. ${ }^{18}$ I pored teškog duševnog stanja posle 15 godina provedenih u bol-

15 „Bavljenje naučnim radom održalo me je u životu i to me je spaslo da zaista ne poludim. Kada sam otpušten, ja sam iz zatvora izneo 217 kila naučnog materijala. Tri puta su mi menjali dijagnozu, prvo ovi iz Sarajeva bili napisali kverulatrija, a kverulatrija je pravni termin za drvene advokate, to nije bolest. Kasnije me zovu da mi upišu dijagnozu psihopata, a na kraju kad je izbila frka pred Ujedinjenim nacijama napišu naučna fenomenologija." Svedoči i da je u zatvoru trovan olovom: Smrtna kazna sa trajnim izvršenjem, intervju sa R. Veljkovićem, Duga, br. 1991.

${ }^{16}$ Svedočenje Gordane Milojević, bivšeg radnika u Centralnom zatvoru - B odeljenje zatvorene neuropsihijatrijske bolnice.

${ }^{17}$ Pismo D. Veljkovića - P. Stamboliću, 7. mart 1983; Arhiva Pokreta za zaštitu ljudskih prava; Odbor za odbranu slobode misli i izražavanja, Dokumenti i saopštenja 19841986, Beograd 1986, dok. br. 12, 37-38 i 39-44.

${ }^{18}$ Apele potpisuju prof. V. Koštunica, K. Čavoški, Lj. Tadić, D. Ćosić, N. Popov, G. Đogo, V. Šešelj i mnogi drugi; Peticija grupe intelektualaca za reviziju sudskih odluka i protiv političke zloupotrebe psihijatrije od 24. novembra 1982; Peticija grupe intelektualaca za reviziju sudskih odluka i protiv političke zloupotrebe psihijatrije od 10. juna 1983; Peticija grupe intelektualaca generalnom sekretaru Ujedinjenih nacija Peresu de Kueljaru za reviziju sudskih odluka i protiv političke zloupotrebe psihijatrije od 24. marta 1984; Peticija grupe građana iz Kruševca i Bele Crkve za oslobađanje R. Veljkovića od 4. oktobra 1983; Peticija grupe intelektualaca Predsedništvu SFRJ za reviziju sudskih odluka i protiv političke zlou- 
nici, Radomir je, prema nalazu više neuroloških klinika u Sarajevu, Beogradu i Ljubljani, dobio dijagnozu: „neurološki nalaz uredan, psihički status uredan". Ocenjen kao natprosečno inteligentan, dobio je pet uverenja da je zdrav od relevantnih neuropsihijatrijskih klinika u Sarajevu i Beogradu, koje dokazuju da je smešten u ludnicu kao psihički zdrav. ${ }^{19}$

Mukama, ipak, nije bio kraj. Po izlasku s robije živi u Sarajevu gde ga zatiče rat i 1992. godine biva zatočen u logor u ustanovi Ramiz Salčin na Koševu kao „sumnjiv i špijun Beograda i generalštaba JNA“. Biva podvrgnut torturi, tri puta pada u komu. Oslobođen je tek posle apela međunarodnih organizacija, podstaknutim inicijativom Pokreta za zaštitu ljudskih prava, čiji je bio član. ${ }^{20}$ Treći put je kao čovek "opasan po okolinu“ (dg. Psihschosis paranoides - organski poremećaj ličnosti) smešten u psihijatrijsku bolnicu u Vršcu 28. juna 2004.

Tragičan je i slučaj novinara Vladimira Markovića (Leskovac, 1952) koji je posle gimnazije u Beogradu upisao najpre Višu turističku školu, zatim završio Jugoslovensku školu za novinarstvo (1976) i bavio se nezavisnim novinarstvom, posećujući mnoge disidente. Vlastima je postao sumnjiv kada je polovinom 70-ih postao član Ancient Astronaut Society kao i zbog interesovanja koje je pokazivao za denikenizam, usled čega je i prekršajno osuđivan..$^{21}$ Krajem avgusta 1976, na zahtev policije, veštačen je od neuropsihijatra dr Tešića u bolnici „Laza Lazarević“, koji je potvrdio da Marković nije opasan po okolinu rečima: „Vladimir Marković možda jeste malo čudan i na svoju ruku. Međutim on nije psihički bolestan. Prema tome nije mu ovde mesto, pogotovu iole duže."22

Marković je drastičnije proganjan zbog interesovanja za srpsku i hrvatsku političku emigraciju. Objavljivao je u emigrantskim časopisima, Naša reč tokom 1976-1977. i listu Hrvatska država od 1978. Optužen je kra-

potrebe psihijatrije od 2. juna 1984; Apel Odbora za odbranu mišljenja i izražavanja Skupštini SFRJ i Skupštini Srbije protiv zloupotrebe psihijatrije, 10. mart 1987. potpisao Dragoslav Mihailović; Smrtna kazna sa trajnim izvršenjem, intervju sa R. Veljkovićem, Duga, 1991; Rešenje o otpustu, Viši sud u Sarajevu, 27. januar 1987; Rešenje o otpustu Radomira Veljkovića KP bolnice Beograd od 17. marta 1988, Arhiv Pokreta za ljudska prava - u posedu autora.

19 Neurološki nalaz Doma zdravlja Sarajevo 712/88, Univerzitetske psihijatrijske klinike u Beogradu 26. februar 1991, Univerzitetske klinike u Ljubljani 12. april 1990. i Vojne bolnice u Sarajevu 1396/88.

${ }^{20}$ Apel pokreta za zaštitu ljudskih prava u Jugoslaviji od 23. aprila 1993; Arhiva Pokreta za zaštitu ljudskih prava.

${ }^{21} \mathrm{~V}$. Marković je pozivan na informativne razgovore u SDB, pa osuđen prekršajno na 30 dana od opštinskog sudije. Denikenizam, po Erihu fon Denikenu, osnivaču društva ljubitelja naučno-fantastičnih ideja, predstavlja verovanje u postojanje viših oblika života i razumnih bića na drugim planetama što utiču na život na Zemlji.

${ }^{22}$ Svedočenje Vladimira Markovića iz Beograda 22. oktobar 2009. 
jem 70-ih zbog intervjua sa Franjom Tuđmanom, koji se zalagao za neku vrstu konfederacije i osporavao broj žrtava u Drugom svetskom ratu na teritoriji NDH, posebno u Jasenovcu (marta 1978), kao i sličnih razgovora sa E. Kocbekom i Nevom, kćerkom Franca Miklavčiča i drugim poznatim disidentima. Razgovor sa Tuđmanom verno je pretvorio u intervju i u leto 1978. poslao Našoj reči, Hrvatskoj državi, slovenačkoj Klic Triglava u Londonu i još nekim emigrantskim glasilima. Fotokopije razgovora sa Tuđmanom, Kocbekom i ćerkom F. Miklavčiča razaslao je na adrese drugih poznatih disidenata (F. Leskošeku, V. Vidmaru...) ali i političkih i državnih rukovodilaca (M. Planinc, D. Dragosavcu) i kulturnih radnika (M. Krleži, P. Matvejeviću). Tuđman je $\mathrm{u}$ intervju osuđivao ustaške zločine, ali je tvrdio da je $u$ Jasenovcu ubijeno samo oko 60.000 lica nasuprot oficijelnim podacima od $700.000 .{ }^{23}$ Posle objavljenog intervjua Marković je 20. oktobra 1978. optužen pred Drugim opštinskim sudom u Beogradu zbog članaka u Hrvatskoj državi jer je, između ostalog, „izazvao uznemirenje i neraspoloženje kod građana“ objavljivanjem Tuđmanovih „neistinitih“ tvrdnji, pa je okrivljen po članu $218 \mathrm{KZ}$ SR Srbije zbog „krivičnog dela širenja lažnih vesti“. Osuđen je rešenjem Drugog opštinskog suda u Beogradu 23. februara 1979. na kaznu vremenski neograničenog lečenja u zatvorskoj bolnici zatvorenog tipa. Nije pomogla Markovićeva žalba Predsedništvu SFRJ, gde je ukazivano na sve nelogičnosti i besprincipijelnosti optužbe. Na suđenju je zloupotrebljena činjenica da je Marković u leto 1970. godine proveo tri nedelje u sanatorijumu otvorenog tipa psihijatrijske bolnice na Avali, zbog lakših pubertetskih problema $u$ ponašanju. Presudom je oglašen neuračunljivim, opasan po okolinu i na neodređeno vreme poslat na lečenje u neuropsihijatrijsko odeljenje zatvorenog tipa, po članu 63 KZ SFRJ. Veštaci koji su ga u sudskom postupku proglasili neuračunljivim, bili su neuropsihijatri primarijusi iz beogradske zatvorske bolnice - dr Vukosav Vučković (upravnik) ${ }^{24}$ i dr Božidar Dželebdžić. Advokat Vladimira Markovića se žalio OKS u Beogradu, ali bezuspešno. Marković je od 23. maja 1979. do 2. aprila 1982. bio na neuropsihijatrijskom „A“ odeljenju KPD bolnice u Beogradu, na četvrtom spra-

${ }^{23}$ Franjo Tuđman je u periodu mart-avgust 1978. i kasnije više puta iznosio ovakve i slične stavove u intervjuima za švedsku televiziju, što su preneli mnogi strani dnevnici ali $u$ kritičkoj formi i Politika, Novosti i Vjesnik, zbog čega je Marković inače zapravo krivično gonjen. - AJ, Predsedništvo SFRJ, 803, fasc. 665, 03-09, 719/1978; Predstavka Vladimira Markovića Kabinetu Predsednika Republike, 21. novembar 1978, 1-2; Odgovornost države Hrvatske za genocid nad srpskim i drugim narodima 1941-1945, 1991-1995, Beograd 2008, 112.

${ }^{24}$ Neuropsihijatar dr Vukosav Vučković, predsednik Udruženja penologa Srbije, $\mathrm{u}$ predgovoru prvog broja Penološkog glasnika nadahnuto kaže: „Pomoći onom koji je pogrešio, pripremiti od društva osuđene najbolji je način da mu se zdravi vrate... jer socijalizam nisu samo fabrike nego i čovek, zbog čega sve to i gradimo“. - Penološki glasnik, Beograd 1978, 2-3. 
tu CZ-a, u teškim uslovima. O robijanju u ovoj zatvorskoj ustanovi kaže: „Uslovi su bili jako loši, hrana, grejanje, prozori su bili razlabavljeni i stari, na sve strane je duvalo... Jedino što smo imali posete jednom nedeljno šest sati... Bilo je ljudi koji su bili ozbiljno bolesni, a bilo je i onih koji su na prvi pogled potpuno zdravi. Onih koji su po osnovu verbalnog delikta bili na ovom odeljenju bilo je svega šest do sedam. Verbalni deliktaši su uglavnom izgledali normalno i ponašali se primereno. Neki su doista imali blage poremećaje koji su se kasnije usled dugog boravka i loših fizičkih uslova i psihičkog pritiska pogoršavali, a ljudi su postajali sve nenormalniji. Pa i zdrav čovek bi poludeo. ${ }^{25}$ Ne retko se događalo da stražar-komandir, jedan ili više njih, videći da se dva zatvorenikabolesnika tuku ili jedan vuče drugoga, počnu udarati pendrekom, šakom, pesnicom ili nogom obojicu bez obzira ko je počeo..." 26

Verovatno bi još dugo bio u Centralnom zatvoru da nije februara 1982. izašla brošura Amnesti internešenela u kojoj se pominju slučajevi Vladimira Markovića i Vjekoslava Naglića kao primeri zloupotrebe psihijatrije u Jugoslaviji, posle čega je ubrzo pušten. Kaznena mera zatvora bila mu je zamenjena blažom „merom obaveznog psihijatrijskog lečenja na slobodi“ (čl. 64 KZ SFRJ). Bio je dužan da se redovno javlja u neuropsihijatrijsku bolnicu sve do 1984. godine. Markovića je novembra 1989, pregledao veštak neuropsihijatar dr S. Mikić iz Instituta za psihijatriju Kliničkog centra Srbije i utvrdio da je potpuno duševno zdrav. „U vreme pregleda dobro kompenzovan, ne pokazuje znake duševne bolesti“ - glasila je dijagnoza. Po izlasku nije mogao da nađe stalan posao, bio je nadalje nadgledan i diskriminisan. Nastavlja sa disidentskim aktivnostima kroz kontakte sa poznatim srpskim i hrvatskim intelektualcima i političkim emigrantima, kao član disidentske grupe za zaštitu ljudskih prava Akcija, koju je predvodio Tomislav Krsmanović. Indikativno je da je novinar koji je objavio intervju zapravo teže kažnjen nego Franjo Tuđman, bivši visoki partijski funkcioner SKJ, koji je izneo sporne podatke. Tuđman je početkom 1981. osuđen na svega 3 godine zatvora, od kojih je odležao manje od dve kada je uslovno pušten na slobodu, dok je za Markovića pitanje kad bi uopšte izašao na slobodu da se za njegov slučaj nije zainteresovao Amnesti internešenel. ${ }^{27}$

${ }^{25}$ Svedočenje novinara Vladimira Markovića iz Beograda dato autoru 12. novembra 2008.

${ }^{26}$ Isto.

${ }^{27}$ Neobjavljen dokumentarni materijal o slučaju Vladimira Markovića ustupljen dobrotom Vladimira Markovića; Naredba istražnog sudije Drugog opštinskog suda Mirjane Melić za veštačenje Kr. br. 322/78, 13. novembar 1978, Predlog javnog tužioca o izricanju mere bezbednosti obaveznog psihijatrijskog lečenja, 11. decembar 1978, Kt-1404/78; Rešenje Drugog opštinskog suda u Beogradu o izricanju mere bezbednosti obaveznog psihijatrijskog lečenja, Kt. 1901/78, 23. februar 1978; Rešenje Drugog opštinskog suda u Beogradu o ukidanju mere bezbednosti obaveznog psihijatrijskog lečenja, Kv. 483/81; Otpusna lista iz KPD bolnice u Beogradu br. 24-954-05-1, 2. april 1982; Intervju autora sa Vladimirom Mar- 
Poznat je i slučaj Dušana Ćetkovića (1927-2009), bivšeg službenika Državne bezbednosti, poreklom iz Nikšića sa stanom u Beogradu, koji je zbog neprijateljske propagande $\mathrm{u}$ zatvorskoj bolnici proveo $5 \mathrm{i}$ po godina (24. april 1978 - septembar 1983) na osnovu rešenja K br. 833/76 Okružnog suda u Beogradu. Sud mu je stavio na teret kažnjive radnje neprijateljske propagande: „...Od druge polovine 1973. do maja 1976. u Beogradu je pozivao na nasilnu i protivustavnu promenu državnog uređenja, svrgavanje predstavničkih tela i njenih organa, razbijanje bratstva i jedinstva naroda Jugoslavije, zlonamerno i neistinito prikazivao društveno-političke prilike u našoj zemlji, izlagao poruzi SFRJ, njenu zastavu i grb... na taj način što je pisao pamflete, umnožavao ih na pisaćoj mašini i predavao ih ambasadama i konzularnim predstavništvima stranih zemalja u Beogradu... gde je tvrdio da u Jugoslaviji narod nema pravo ni onoliko koliko je to imao u bivšoj Jugoslaviji, kada je javno mogao da postavlja pitanja kraljevske liste i apanaže dok 'sinovi naroda' ne smeju ni sada pitati 'proleterskog vođu' ni kako mu je pravo ime". Tvrdio je da je jugoslovenska država gora od Hitlerove tvorevine, donela je najviše štete i zločina čitavom svetu, u Jugoslaviji nema zakona, najviši predstavnici SFRJ gori su od svakog esesovca i čine međunarodni zločin delujući u pravcu razbijanja bratstva i jedinstva jugoslovenskih naroda. Izlažući poruzi predsednika SFRJ nazivao ga je "najvećim zločincem sveta“, a najviše rukovodioce državnih organa "prevejanim kriminalcima i ubicama“ ${ }^{28}$

Živojin Živković (1945), iz sela Oglađenovac kod Valjeva, invalidski penzioner. Desetak puta je hapšen i nasilno smeštan u psihijatrijske bolnice u Valjevu i Beogradu. U KP domu bolnice u Beogradu boravio je od juna 1977. do juna 1980. Izrečena mu je mera bezbednosti od Opštinskog suda u Valjevu. Proganjan je iz političkih i verskih razloga, više puta privođen, brutalno premlaćivan od policije kao član i vernik Jehovinih svedoka propovedajući njihove poglede na brak, porodicu i vaspitanje dece. Pod prismotrom su bili i braća Slobodan i Života, sestra Božidarka i roditelji koji su više puta nasilno smeštani u zatvorske bolnice kao vernici i svedoci Jehove. ${ }^{29}$ Jovan Lukić (1935), trgovački radnik - invalidski penzioner iz Sarajeva, dobio je 1964. otkaz jer je kao poslovođa prodavnice kritikovao malverzacije i krađe, raskrinkavao osobe i srodnike uticajnih političkih ličnosti. Poveo je radni spor u borbi za svoja prava. Rešenjem SUP-a Sarajevo nasilno je

kovićem, 2. novembar 2007; Yugoslavia Freedom to conform, U. S. Helsinki Watch Commitee, New York, August 1, 1982, 17; Dosije Ko je ovde lud, Heretikus 1/2007, Beograd 2007; V. Marković, Za ljudska prava - moje disidentske uspomene, Beograd 1999, 51-67.

${ }^{28}$ AJ, Predsedništvo SFRJ, 803, fasc. 648, Komisija za pomilovanje 03-05/1977, Dosije Dušan Ćetković; K. Čavoški, Preliminarni izveštaj o zloupotrebi psihijatrije u političke svrhe, 15. februar 1985, Odbor za odbranu slobode misli i izražavanja, Dokumenti i saopštenja 1984-1986, Beograd 1986, dok. br. 12, 37-38 i 39-44.

${ }^{29}$ Slučaj Živojin Živković, Arhiva Pokreta za zaštitu ljudskih prava. 
smešten od strane milicije na neuropsihijatrijsko odeljenje Sarajevske bolnice, gde je bio od kraja oktobra 1974. do kraja januara 1975. U bolnici je izlagan torturi elektro-šokovima, usled čega je nastupio invaliditet i teško oštećenje zdravlja. Božidar Boričić (1927), bez zanimanja, pacijent psihijatrijskih bolnica u SFRJ i NR Albaniji od 1948. godine. Osuđen je zbog tvrdnji da su politički sistemi SFRJ i NR Albanije slični, još uvek staljinistički. Vlasti su iskoristile njegov blaži prekršaj (krađa u samoposluzi) da ga smeste u Centralni zatvor na neuropsihijatrijsko odeljenje na osnovu presude OKS u Beogradu 1974. godine. Tu se nalazio sve do amnestije 1985, posle apela javnosti i napisa u štampi novinara Vladimira Markovića koji je sa njim proveo 3 godine u zatvoru. Jugoslovenski državljanin poljskog porekla Sjenkijevič, koji je napao antititoistički spis u emigraciji (Švedska) proveo je 3 godine, 1975-1978, u beogradskoj zatvorskoj bolnici, kada je oslobođen zalaganjem švedskih vlasti i mas-medija. ${ }^{30}$

Nešto veći broj slučajeva zloupotrebe psihijatrije zabeležen je $\boldsymbol{n a}$ teritoriji Vojvodine. Tako je Milislav Živanović (1911-2000) penzioner iz Pančeva, rešenjem OKS u Pančevu K-88/76, poslat u psihijatrijsku ustanovu zatvorenog tipa na neograničeno lečenje (nalaz Paranoia querlatoris manija parničenja, neuropsihijatrijske klinike u Vršcu od 14. januara 1976) zbog izlaganja poruzi (čl. $157 \mathrm{KZ}$ ), tj. optužbi za korupciju i bezakonje najviših organa SFRJ, SR Makedonije i klevetanja Ante Marine, Nikole Minčeva i Kire Gligorova. Interniran je 1976-1978. u psihijatrijsku bolnicu Vršac, zatim i na Neuropsihijatrijsko odeljenje CZ-a u Beogradu 1986, kada je Odbor za odbranu slobode misli i izražavanja intervenisao, bio je više od 9 godina u zatvorskoj bolnici, ali je i dalje pokazivao zavidan stepen sabranog i razumnog ponašanja. ${ }^{31}$ Đorđe Simičić (1935-1989) iz Iloka kod Novog Sada, rešenjem OKS u Novom Sadu proveo je, po izricanju kazne, 8 godina $\mathrm{u}$ bolnici zato što je u Iloku i Titelu od početka do marta 1977. napisao i rasturao dvadesetak letaka protiv Tita i socijalističkog društva, čime je učinio krivično delo „povrede ugleda države i njenih organa“, a što je predstavljalo krivično delo "neprijateljske propagande“. U predlogu Okružnog javnog tužilaštva za izricanje mere bezbednosti od 9. juna 1977. kaže se: „...Jer pisanje i rasturanje letaka sa neprijateljskom sadržinom izazivalo je i izaziva uznemirenje u javnosti, smatramo da je okrivljeni opasan po društvo i za svoju okolinu, te da su time ispunjeni uslovi iz čl. 454 stav 11. ZKP u vezi čl. 61. st. 1. $K Z$, pa se prema njemu predlaže mera bezbednosti upućivanja u Zavod za duševno bolesna lica ili drugi zavod za čuvanje i lečenje." U mišljenjima okri-

${ }^{30}$ Zloupotreba psihijatrije u političke svrhe (7), Svetlost, br. 5, Kragujevac 1991, 1314; 17-18; Svedočanstva 16. decembar 1992, 41.

${ }^{31}$ K. Čavoški, Preliminarni izveštaj o zloupotrebi psihijatrije u političke svrhe, 15. februar 1985, Odbor za zaštitu sloboda mišljenja i izražavanja - u posedu autora. 
vljenog, kako se navodi, postoje elementi sumanutog i ta vrsta poremećenosti kod njega prisutna je poslednje četiri godine. U zatvoru, u Bačvanskoj 14 u Beogradu, teško je oboleo i ostao nepokretan, da bi ubrzo preminuo $1989 .{ }^{32}$

Zanimljiv je slučaj Mileta Labusa. Posle poraza liberala u SK Srbije i dolaska na vlast Dušana Alimpića (posle rata visokog funkcionera Službe bezbednosti), suđeno je ovom nosiocu Partizanske spomenice 1941, penzionisanom 1953. godine. Labus je bio oduševljen pismom Josipa Broza iz septembra 1972, smatrajući da se komunizam vratio svojim izvornim korenima i da je nastupila „čvrsta ruka" u obračunu sa neprijateljima socijalizma. Ubrzo je došao u sukob sa Dušanom Alimpićem (bivšim šefom koji ga je penzionisao), nakon što je Labus počeo da šalje tekstove na adrese različitih redakcija (list Dnevnik, TV Novi Sad i drugih) u kojima je Alimpića nazvao „velikosrpskim šovinistom", „četnikom", „neprijateljem socijalizma“. Zbog toga je uhapšen i suđen pred OKS u Novom Sadu. Psihijatrijski veštaci (tri ugledna neuropsihijatra sa Medicinskog fakulteta u Novom Sadu), predlažu da mu se izrekne mera obaveznog lečenja u ustanovi zatvorenog tipa. Advokati su insistirali na tome da pisanje pamfleta ne može biti „opasno po okoli$n u^{\prime \prime}$ i razumevanje su našli kod članova veća (starih boraca), pa je predlog odbrane prihvaćen. Na žalbu tužioca, Vrhovni sud Vojvodine i predsednik veća sudija Perić preinačavaju prvostepenu odluku i Labusa nasilno odvode na psihijatrijsko odeljenje KP bolnice u Beogradu. Branioci su se žalili Saveznom javnom tužilaštvu tražeći zaštitu zakonitosti. Spasoje Đaković, javni tužilac, prima advokata i otvoreno obrazlaže: „Alimpićeve zasluge za revoluciju su sveže, u borbi protiv liberala i Mirka Čanadanovića u Vojvodini." Savezno tužilaštvo, imajući u vidu Labusove ratne zasluge, podiglo je zahtev za zaštitu zakonitosti. Na obnovljenom procesu pred Saveznim sudom Labus je, zahvaljujući mišljenju veštaka, posle više od 2 godine oslobođen i prebačen na ambulantno lečenje. ${ }^{33}$

Na sličan način proganjan je i Stevan Poznić (1949-1997), inače blizak Labusov rođak, inženjer iz Banatskog Plandišta. Smešten je 13. maja 1977. u Centralni zatvor u Beogradu (neuropsihijatrijsko odeljenje) nakon što je optužen da je počinio ubistvo u samoodbrani (osuđen 1977. od OKS u Pančevu). Prema njegovoj izjavi i podacima grupe Akcija, radilo se o političkoj osveti prema njegovom ocu Nikoli Pozniću (bivšem direktoru ugostiteljskog preduzeća Avala iz Plandišta) koji je 1971. dobio politički motivisan otkaz. Od tada se on i njegova porodica izlažu progonu. Nikola Poznić je nekoliko puta slat na psihijatrijsku ekspertizu. Zbog podrške Pozniću,

\footnotetext{
${ }^{32}$ Isto.

${ }^{33}$ Slučaj Mila Labusa, Arhiva Pokreta za zaštitu ljudskih prava; R. Danilović, $n$. d; T. Krsmanović, $n$. d.
} 
više osoba je na sličan način proganjano: inž. Dušan Poznić (Nikolin brat) bio je prisilno smešten nekoliko meseci u bolnicu „Laza Lazarević“ Padinska skela. P. Manojlović, bivši predsednik opštine Plandište, takođe je više meseci proveo u Vršačkoj bolnici. Od jula 1983. građani Plandišta pokrenuli su više peticija za prekid progona porodice Poznić, o čemu je pisala i štampa. ${ }^{34}$

Poznati su neki primeri zloupotreba psihijatrije na Kosovu u slučaju Radoslava Dragovića (1937), radnika Jugobanke u Kosovskoj Mitrovici. Kao navodni „instruktor Nove KPJ“ čiji su pripadnici pohapšeni, osuđen je 18. novembra 1974. pred OKS u Peći zbog neprijateljskog delovanja po liniji IB-a, a kao navodno neuračunljiva i psihički bolesna osoba „opasna po okolinu“ osuđen je najpre na 7 godina i upućen na lečenje u zatvorsku neuropsihijatrijsku bolnicu u Beogradu. ${ }^{35}$ Bajram Ajeti (1954) iz Podujeva, pripadnik Grupe marksista-lenjinista Kosova, tokom 1984. osuđen je na meru bezbednosti lečenja $u$ neuropsihijatrijskoj bolnici zatvorenog tipa na neograničeno vreme, pošto je, navodno, utvrđeno da boluje od paranoidne šizofrenije. U zatvorskoj bolnici proveo je 3 godine, a pušten je posle intenzivnog zauzimanja organizacija za zaštitu ljudskih prava (Amnesty internešenel) i grupe Akcija. ${ }^{36}$

Jedan od najupornijih boraca protiv zloupotrebe psihijatrije, i sam žrtva progona, jeste Tomislav Krsmanović (1936) iz Beograda. Završio je Ekonomski fakultet u Beogradu 1963. i postdiplomske studije iz istraživanja tržišta na Katoličkom institutu za visoke komercijalne studije (1969) u Briselu, gde je pripremao doktorat koji nije odbranio usled povratka $\mathrm{u}$ zemlju i progona koji su usledili. Osnovao je, 1. marta 1975, prvi jugoslovenski odbor za zaštitu ljudskih prava Direktna akcija za samozaštitu. Krajem 80-ih organizacija je omasovljena i preimenovana u Pokret za zaštitu ljudskih prava, iz kojeg je nastalo nekoliko masovnih organizacija do kraja 80 -ih. U ime te organizacije obratio se 1 . juna 1975. pismom J. B. Titu tražeći pravo i slobodu za izražavanje mišljenja i slobodu dijaloga, kao i neophodnost uvođenja parlamentarne demokratije. Dana 21. juna 1975. biva uhapšen ispred svog stana posle sastanka neformalne organizacije čiji je bio član. Optužen je „da je ispisivao ključem po zidovima kluba i susednih zgrada da je crvena zvezda jednaka kukastom krstu“. Priveden je u gradski SUP, gde je saslušavan, kao i u RSUP. Odveden je u psihijatrijsku bolnicu „Laza Lazarević“, gde je podvrgnut psihijatrijskom ispitivanju. Trojica lekara su

${ }^{34}$ Slučaj Stevan Poznić, Arhiva Pokreta za zaštitu ljudskih prava.

35 AJ, Predsedništvo SFRJ, 803, fasc. 648, Komisija za pomilovanje 03-05/1977, Komisija za pomilovanje Kosova - predlozi.

${ }^{36}$ B. Ajeti je tokom 1988. oformio terorističku grupu i činio zločine, a pred poterom sa preživelima iz gerilske grupe prebegao je u Albaniju: T. Krsmanović, Ko je ovde lud, 44; V. Marković, Za ljudska prava - Moje disidentske uspomene, 92. 
okarakterisali da boluje od paranoične šizofrenije i nezasluženo blati zemlju "koja je poznata u svetu po poštovanju ljudskih i političkih prava“. Prema rečima Krsmanovića, uslovi u ustanovi bili su loši i nehigijenski. Govori o mnogim slučajevima koje je tamo upoznao, a koji su bili žrtve političkog progona (zbog lakših psihičkih problema) i proglašavani neuračunljivim i opasnim po okolinu. Tu se zainteresovao za praksu zloupotrebe psihijatrije za koju je čuo da se masovno koristi u SSSR-u. Posle apela i napisa u inostranim medijima biva pušten iz bolnice 1. jula 1975. Povodom ličnog progona pisao je Ujedinjenim nacijama i tražio izveštaj lekara specijaliste neuropsihijatrijske klinike VMA u Beogradu, koja mu je nalazom od 24. oktobra 1977. potvrdila da je potpuno psihijatrijski zdrav. ${ }^{37}$

Odbor za odbranu slobode mišljenja i izražavanja je 1. juna 1986, na osnovu podataka Pokreta za zaštitu ljudskih prava, predložio Skupštini da se obrazuje komisija koja bi preispitala 40-ak slučajeva za koje se osnovano sumnja da su žrtve zloupotrebe psihijatrije i zahtevao je puštanje ovih verbalnih delinkvenata na slobodu. Tražilo se unošenje u čl. $63 \mathrm{KZ}$ odredbe kojom se onemogućava da bilo ko bude osuđen na meru vremenski neograničenog smeštanja u duševnu bolnicu za ono što misli ili govori. Harold Visocki, predsednik komiteta za borbu protiv zloupotrebe psihijatrije, uputio je pismo predsedniku jugoslovenskom psihijatrijskog udruženja, u kojem je zamolio za obaveštenja i odgovarajuće dokumente u slučaju R. Veljkovića, D. Ćetkovića, B. Boričića, Ž. Živkovića i V. Naglića. Isto su učinili Dansko udruženje lekara i Koventri grupa Amnesti internešenela. Kosta Čavoški, u odgovoru na napade, u Novostima navodi slučaj kažnjavanja Dragomira Dragićevića, rođenog 1913. u Ćupriji sa stanom u Beogradu, koji je 1978, u 65. godini života, upućen u duševnu bolnicu zatvorenog tipa i tamo proveo 29 meseci samo zato što je u kafani pitao: „Ko je ovaj ovde?" pokazujući pri tom na sliku J. B. Tita. Peticija intelektualaca je tokom januara odjeknula u svetskoj javnosti (BBC, Dejli telegraf, Dojče vele, Glas Amerike...), ali je od režimskih glasila dočekana na nož, a neki mediji (Večernje novosti) potrudili su se da zavire $u$ karton osuđenih i naprave intervju sa nepotpisanim lekarima specijalistima. ${ }^{38}$

${ }^{37}$ Krsmanović je dobio više međunarodnih priznanja (Američkog udruženja psihijatara, Svetske asocijacije psihijatrije, Amnesty internešenela, UNESKA, itd.) jer je svojim delovanjem doprineo da se obznani praksa zloupotrebe psihijatrije u političke svrhe i pružio podršku velikom broju žrtava bezakonja; T. Krsmanović, n. d., 68-76; Svedočenje Tomislava Krsmanovića iz Beograda dato autoru 27. novembra 2007; Yugoslavia Freedom to conform, U. S. Helsinki Watch Commitee, New York, August 1, 1982, 17.

${ }^{38}$ Apel Odbora za zaštitu slobode mišljenja i izražavanja - Skupštini SFRJ i Skupštini Srbije protiv zloupotrebe psihijatrije u slučaju Vladimir Marković, Milisav Živanović, Radomir Veljković, Đorđe Simičić, Dušan Ćetković i drugi, 6. januar 1986; Arhiva Pokreta za zaštitu ljudskih prava; Pucanj u činjenice i podmetanje istini, Večernje novosti, 31. januar i 1. 
Postoje podaci da su se lica kažnjavala na osnovu neadekvatno počinjenih krivičnih dela i za nepolitičke delikte. Janoš Vibok (1951) provodi dve decenije (1971-1990) na psihijatrijskom odeljenju Centralnog zatvora, osuđen kao član omladinske prestupničke grupe, iako mu je psihičko stanje bilo daleko od toga da bude "opasan po okolinu“. Novinar Vladimir Marković o njemu kaže: „Stevan Poznić i Janoš Vibok bili su moji dobri drugovi na 'A odeljenju' specijalne Psihijatrijske bolnice beogradskog Centralnog zatvora i ja o njima mogu reći samo najbolje - mirni i čestiti ljudi." ${ }^{39}$ Zbog mnogih zloupotreba, Komitet za zaštitu ljudskih prava se 15. januara 1988. obraća peticijom državnim organima i Udruženju psihijatara Jugoslavije s predlogom da se izmeni Zakon o vanparničnom postupku SR Srbije - glava II Zadržavanje u ustanovama lica koja nisu počinila nikakvo krivično delo nego što to zahteva njihovo stanje zdravlja, tvrdeći da su zloupotrebe po ovom zakonu mnogo češće nego po krivičnom postupku zbog nepreciznosti zakona, što se tumači prema ličnom nahođenju sudije. Ističe se potreba da se, zbog pravne sigurnosti, nejasni i neodređeni zakoni zamene preciznom zakonskom regulativom.

Pored kažnjavanja smeštanjem u psihijatrijske bolnice po članovima 63 i $65 \mathrm{KZ}$ SFRJ, Pokret za zaštitu ljudskih prava ima podatke da je 70-ih i 80-ih bilo slučajeva konfiniranih po građanskom-vankaznenom postupku. Kao primer navodi se Zoran Stanković, nastavnik iz Beograda, poreklom iz Pirota, koji o progonima porodice kaže: „Moj deda je bio ugledni oficir kraljevske vojske iz ugledne trgovačke porodice u Pirotu. Posle oslobođenja oni su oglašeni za kolaboracioniste, a celokupna imovina je konfiskovana. Svi smo vukli negativne karakteristike, nismo mogli da nađemo zaposlenje. Stalno psihički proganjani i maltretirani doživljavali smo porodične traume. Završio sam francuski jezik i preselio se u Beograd u nadi da ću lakše naći posao. Zbog kritike režima 1982. i posle pritisaka na moju majku oglašen sam neuračunljivim i poslat u bolnicu 'Laza Lazarević' u Padinskoj skeli (1982)“. ${ }^{40}$ Milica Bobić (1950) je protiv svoje volje smeštena u psihijatrijsku bolnicu Laza Lazarević u Padinskoj skeli kod Beograda, gde ostaje do 19. novembra 1984. zbog izražavanja verskih ubeđenja na društveno neprihvatljiv način i slaveći krsnu slavu Svetog Jovana. Milica Todorović, profesorka srednje škole iz Čačka, hospitalizovana je 1985. zbog kritikovanja reforme usmerenog obrazovanja i stanja u školstvu, a Vera Bljajić Karagić (1926), invalidski penzioner iz Beograda, jer je objavila

februar 1986; Delikt mišljenja kao duševna bolest, Odgovor Koste Čavoškog Večernjim novostima, 10. februar 1986. Odbor za odbranu mišljenja i izražavanja; O Dragićeviću se jedno vreme starao i akademik Dragoslav Mihailović; T. Krsmanović, Ko je ovde lud, 86-87.

${ }^{39} \mathrm{~V}$. Marković, Za ljudska prava - Moje disidentske uspomene, 91-92.

${ }^{40}$ T. Krsmanović, Kaznena psihijatrija 1975-2004, Ko je ovde lud?, 115. 
knjigu u kojoj razmatra materiju parapsihologije i zalaže se za pluralistički sistem. ${ }^{41}$

Za sada ostaju neistraženi slučajevi zloupotrebe psihijatrije $u$ drugim republikama SFRJ. Poznati su slučajevi u Hrvatskoj, od kojih, na osnovu podataka Pokreta za zaštitu ljudskih prava, izdvajamo samo nekoliko karakterističnih: Vjekoslav Naglić (1949), radnik iz Vinkovaca, pre smeštanja u bolnicu živeo je sa roditeljima u Švedskoj. Stavljeno mu je na teret krivično delo „neprijateljske propagande“ za vreme služenja vojnog roka. U istrazi je ispitan od vojnih psihijatara u Sarajevu (ukazali da je delo učinio u stanju duševnog rastrojstva), pa mu se rešenjem Vojnog suda $u$ Sarajevu od 18. juna 1975. određuje obavezno lečenje u bolnici po članu 63 KZ SFRJ. Do oktobra 1983. boravio je u KP bolnici u Beogradu, a od tada u Psihijatrijskoj bolnici Dr Ivan Barbot u Popovači. Ivo Maleš (1943), ugostiteljski radnik iz Babinog polja (ostrvo Mljet), od strane OKS u Dubrovniku 1981. smešten je u psihijatrijsku bolnicu Ugljen zbog činjenja političkog delikta verbalne prirode i pisanja političkog pamfleta. Vladimir Perišić (1950), radnik iz Šibenika, rešenjem od 14. oktobra 1982, zbog „neprijateljske propagande" i povrede ugleda države i njenih organa proglašen je od tima psihijatara zagrebačke psihijatrijske bolnice duševno neuračunljivim i „opasan po okolinu“ pa mu je, po tom osnovu, izrečena mera obaveznog lečenja u duševnoj bolnici (Zagrebu i Popovači). Domagoj Paraga (1959) komercijalista iz Zagreba, brat poznatog disidenta i borca za ljudska prava, bio je kao mladić nasilno smešten na više meseci u psihijatrijsku bolnicu u Zagrebu. Mile Gvojić je 1969. došao u sukob sa opštinskim moćnicima u Karlovcu, pa je zbog verbalnog delikta osuđen pred opštinskim sudom i upućen u Beograd u zatvorsku bolnicu na lečenje, gde je podvrgavan torturi jer je nastavio da se bori za svoja prava. Otpušten je iz bolnice 1980, ali u invalidskim kolicima. ${ }^{42}$

O tome koliko je sofisticirana i perfidna bila zloupotreba psihijatrije svedoče i muke kroz koje danas prolaze lica koja pokušavaju da se rehabilituju pred sudovima u Srbiji. Budući da po pravilu nisu bila zvanično osuđena zbog političkih inkriminacija jer su mere bezbednosti izricane na osnovu „objektivnog" veštačenja neuropsihijatara veštaka, danas je veoma teško dokazati su bili politički osuđenici i da u tom momentu nisu bili opasni po okolinu. Druga strana uvek može da kaže da su se oni kao takvi ili „izlečili“ $\mathrm{u}$ uslovima zatvorske bolnice i da danas zaista nisu opasni po okolinu. U suprotnom slučaju, kada se psihičko stanje inače relativno normalnih ljudi

${ }^{41}$ Isto, 51-61.

${ }^{42}$ Zloupotreba psihijatrije u političke svrhe (7), Svetlost, br. 5, Kragujevac 1991, 19; T. Krsmanović, $n$. d., 43. 
$\mathrm{u}$ bolnici zaista pogorša, može se reći kako je sudija bio u pravu. Sudije, po pravilu, odbijaju zahteve za rehabilitaciju jer formalistički nalaze da lice nije ni osuđeno iz ideološko-političkih razloga. Tako je, nažalost, postupio i Viši sud u Beogradu u pokušaju rehabilitacije novinara Vladimira Markovića. ${ }^{43}$

Srdjan Cvetković

WHO IS CRAZY HERE? (AB)USE OF PSYCHIATRY IN SFRY

\section{Summary}

Abuse of psychiatry for political purposes appeared massively in USSR and other communist countries since the end of 50s, especially in terms of relative liberalization and de-Stalinization, as well as a need to conceal the real number of political convicts. In socialist Yugoslavia this phenomenon became particularly common since the middle of $70 \mathrm{~s}$, with the strengthening of civil sector, signing international declarations about human rights and the regime`s wish to present itself as a country of liberal socialism after the reforms of the 50s. Criticism of the regime as well as expressing liberal and critical attitudes and opinions were the reason for declaring people dangerous for the environment without any documents or proofs, instead of imprisoning them for political offence. In this way the real number of political convicts was "hidden", and this kind of abuse was a mean of social and political control in the hands of the repressive apparatus. The term "dangerous for the environment" was rather exploited, and its broad interpretation alluded what can be subsumed under ideologicalpolitical diversion.

${ }^{43}$ Viši sud u Beogradu Rešenje o odbijanju rehabilitacije Vladimira Markovića, rex. br. 14. februar 2013. 